\title{
Learning Difficulties in German as a Third Language Experienced by Turkish Undergraduate Students
}

\author{
Ahmet Tanir ${ }^{1}$ \\ ${ }^{1}$ School of Foreign Languages, Iskenderun Technical University, Iskenderun-Hatay, Turkey \\ Correspondence: Ahmet Tanir, School of Foreign Languages, Iskenderun Technical University, Iskenderun-Hatay, \\ Turkey.
}

Received: March 16, 2020

Accepted: April 21, $2020 \quad$ Online Published: May 29, 2020

doi:10.5539/ies.v13n6p131

URL: https://doi.org/10.5539/ies.v13n6p131

\begin{abstract}
The current study aims to investigate learning difficulties in L3 German experienced by the Turkish undergraduate students. The target group involved 29 students from three academic programs at a state university in Turkey: Travel Management and Tourist Guiding, Tourism and Hotel Management and Aviation Management. In the study, semi-structured interview form was designed by the researcher as data collection tool. In the analysis process of the data, the thematic analysis procedure was conducted. The results of the study indicated that the Turkish undergraduate students had learning difficulties in L3 German due to three main factors such as linguistic facts, effective factors and external factors. The linguistic facts involve the learning difficulties related to the linguistic characteristics of German language, linguistic habitus (effect of L2 English) and the effect of L1. In the context of effective factors, it was discussed that the lack of motivation, negative attitudes towards German language, the level of readiness for learning L3 German and the lack of self-confidence lead the students to experience negative learning process in L3 German. Finally, socio-cultural developments and the financial matters emerging in the learning environment were considered as external factors that lead the students to have difficulties in learning L3 German.
\end{abstract}

Keywords: learning difficulties, linguistic facts, effective factors, external factors, L3 German

\section{Introduction}

The low interest in L3 German lessons may lead to both undesirable academic success and German learning difficulties. Therefore, identifying learning difficulties in L3 German is not a problem, but rather a problem-solving strategy for designing more effective learning programs and methods (Jeuk, 2010, p. 94).

Academic studies on learning difficulties in the acquisition of L3 appear to be generally dealt with in the linguistic dimension (e.g. Cenoz, 2001; Jessner, 2003, 2006; Flynn, Vinitskaya \& Foley 2004, De Angelis, 2005; Leung, 2005, 2006; Tremblay, 2006; Bardel \& Falk 2007; cited in Kupisch, Snape, \& Stangen, 2013). Some studies have highlighted that both L1 and L2 have an impact on the L3 learning process (e.g. Jaensch, 2008; Berkes \& Flynn, 2012; Falk \& Bardel 2010; Rothman, 2010, 2013; Şekerci-Arıbaş \& Cele, 2019). In this regard, Epimakhova, Pechinkina, and Tarasova (2019) have suggested that one of the most important factors affecting students' foreign language learning is the language system of L1. This leads them to comparing L1 with the system of L2. According to Ishag, Altmayer, and Witruk (2015), the size of learning difficulties develops negatively, as the differences between L1 and target language increase, and this is the main source of errors in language acquisition. Kolabinova et al. (2015) argued that the structural differences between L1 and the target language should be taught comparatively in the learning process of foreign language, so that language learners can learn the target language more easily and think analytically. On the other hand, Hufeisen (2003, p. 9) argued that the learning difficulties of L3 learners may stem from the differences between L2 and L3. Especially, language learners can establish a strong relationship between the two languages, if the languages are similar to each other. However, cognitive and strategic factors may affect the learning process, as the differences among them increase. Similarly, Lay (2017) reported that not only L1 but also L2 English had an impact on the learning difficulties in L3 German of Chinese students. He stated that Chinese students use positive or negative language transfers consciously and unconsciously while learning German. Therefore, he argued that L3 German learners should learn German, English and Chinese comparatively. The similarities between L2 and L3 may have a positive effect on the learning process and the language use of L2 should be encouraged in L3 acquisition (Groseva, 1998, p. 29). 
However, there are relatively few studies in which the learning difficulties in L3 German are addressed outside the above-mentioned context. Obviously, it cannot be said that the learning difficulties experienced in L3 learning process arise only from linguistic differences. The importance of foreign languages in curriculum may carry the learning difficulties to different dimensions. For example, education policies of countries may affect the learning process in question. L2 English is compulsorily taught in state schools in Turkey. On the other hand, Turkish students are provided with the opportunity to learn a second foreign language in some high schools or institutions. These courses are usually optional, and German is one of them. Students usually consider L3 German lessons as an elective course taken to have graduation degree. This attitude inevitably reduces the interest of students in learning L3 German. Similarly, Iwasaki (2001) stated that L3 German lessons instructed as an elective course in Japan lead most students not to feel compelled to continue learning L3 German. Accordingly, Japanese students have the idea of passing only the course or completing their course credits instead of learning L3 German. From the point of this view, it can be stated that education policies shape students' perspectives on L3 German.

Whether a foreign language is really difficult may be related to the number of words, sentence structure, the worldview which develops depending on the cultural characteristics of the language and the level of readiness of language learners. The differences in the learning level of individuals may be directly proportional to the difficulties experienced while learning a language. Furthermore, individual differences may make it inevitable that the challenges of students in learning a language differ from each other. However, various language difficulties may arise in such a situation. It means that foreign language teachers must cope with the problems stemming from the factors such as attitude, belief, awareness and motivation (Little, 2017, p. 13). Especially, it is assumed that learning success may be related to goal, motivation, strategy and previous learning experiences (Robinson, 2002). This leads foreign language learners to develop their own learning strategies. In other words, foreign language learners assess the difficulties of the foreign language themselves. Additionally, they identify parts of the foreign language that they have difficulty to understand during the learning process and call it as the degree of difficulty experienced in learning foreign language. This means that learners assess themselves their achievements and performances at the level of foreign language learning (Ishag, Altmayer, \& Witruk, 2015; O'Malley \& Valdez-Pierce, 1996). Accordingly, Ehrman and Oxford (1990) claimed that individuals interested in developing their own learning strategies and teaching approach while learning a foreign language have high motivation and their language acquisitions are affected positively. Gardner and Lambert (1959) who are accepted as the first researchers on the importance of motivation determined that the interest in learning a foreign language and the desire on communication in the target language and on learning its culture lead individuals to have a positive attitude towards foreign language learning. In this context, motivation can be considered as one of the most important factors that reveal in a positive or negative way the intentions of students to learn foreign languages.

The literature mostly addresses the learning difficulties experienced in L3 German in a linguistic dimension. The current study expanded this scope a little more and focused on not only linguistic but also what other factors may exist in the learning process of L3 German experienced by Turkish undergraduate students. In the context, the related literature was discussed, and the results of the current study were revealed based on the aim, method and findings.

\section{Method}

\subsection{The Aim of the Current Study}

Basically, it is important to investigate the difficulties experienced by Turkish undergraduate students in learning L3 German. Considering the data obtained as a result of the literature analysis and the problems observed by the researcher during the learning process in L3 German, this study addressed the following one specific research question:

- What are the main learning difficulties in L3 German experienced by Turkish undergraduate students?

\subsection{Target Group}

This study involved 29 students who took "German I" course in the fall semester of the 2019-2020 academic year. They were the 3 rd grade undergraduate students from three different academic programs at the Iskenderun Technical University in Turkey: Travel Management and Tourist Guiding, Tourism and Hotel Management and Aviation Management. Their ages ranged from 20 to 22. According to CEFR guidelines (Council of Europe 2011), their level of German language fell between A1 and A2. Their native language was Turkish. The students were chosen according to the bell curve grading. By taking the frequency distribution of the cumulative grade point average yielded at the end of the midterm and final exam into consideration, 29 of total 147 students whose German I exam average is below 45 participated in the current study (see Appendix B for further details). The students who fell below the mentioned grade were considered unsuccessful. Each of the exams consisted of 4 
section. In first section, there was a 10 questions multiple-choice test relating to German grammar. In the second section, 10 translation questions were given. 5 of these questions were a translation task from Turkish to German and 5 were a translation task from German to Turkish. In the third section, a German reading comprehension text in ranging from 150 to 200 words were given and the students were asked to answer the 5 questions relating to the text. Finally, in the fourth section, there was a C-test based on German vocabulary.

\subsection{Instrument}

In the current study, a semi-structured interview form was used as a data collection tool. The current tool designed by the researcher consisted of seven open-ended questions (see Appendix A). The interview questions were based on the analysis of the current literature regarding the difficulties in teaching and learning German. Two Lecturers who do research on L3 German were consulted to demonstrate the reliability and validity of the data collection tool. The semi-structured interview form originally composed of eleven questions was reduced to seven questions based on feedback from experts. In order to test whether the questions are comprehensible, a pilot study was conducted with a student experiencing difficulty in learning German and consequently, it was determined that there were no problems regarding the interview questions.

\subsection{Interview Procedure}

A meeting was held with the students participated in the study before the process of data collection. The students were informed about the subject and aims of the study. By considering the time interval that students are available, the appointment time was scheduled in order to obtain reliable and valid data. The interviews lasting for 20-25 minutes were recorded with a voice recorder. The interview questions were asked in Turkish. The interview records were transcribed in Microsoft Word. As a result, a data file composed of 82 pages was obtained.

\subsection{Data Analysis}

A thematic analysis procedure was used by the researcher in the analysis of the interviews. The interviews transcripts were analyzed by two experts in the field of German language teaching in order to establish the trustworthiness of the analysis. In this regard, the analysis results were compared and discussed. Accordingly, it was followed the six steps of thematic analysis developed by Braun and Clarke (2006). First, the collected data were overviewed, and the notes were taken. Then, the common phrases and sentences were highlighted and were coded. Next, the codes were looked over and thematized. The themes were reviewed in order to ensure to what extent they were associated with the subject of the current study. Then, each of themes was defined in order to exactly understand the current data. Finally, the analysis of the data was written on the basis of research question and aim. The specific codes and themes determined in the current study with regard to learning difficulties in German experienced by the Turkish undergraduate students were presented as shown in Table 1.

Table 1. The learning difficulties in L3 German as a result of thematic analysis

\begin{tabular}{ll}
\hline Codes & Themes \\
\cline { 1 - 1 } Characteristics of German Language & \\
\cline { 1 - 1 } Linguistic Habitus & Linguistic Facts \\
\cline { 1 - 1 } Effect of Native Language & Effective Factors \\
\cline { 1 - 1 } Motivation & \\
\hline Readiness & External Factors \\
\hline Selfitude & \\
\hline Socio-cultural Developments & \\
\hline Financial Matters &
\end{tabular}

\section{Results}

In this section, the findings were discussed and interpreted under three main themes above identified by directly citing to students' view. The students were coded as "S1, S2, S3..." in order to express their views regarding the difficulties experienced in learning L3 German.

\subsection{Linguistic Facts}

Linguistic facts focus on learning difficulties arising from linguistic characteristics in learning L3 German. Within the scope of the study, students were asked what linguistic characteristics-related learning difficulties might be in 
the learning process of L3 German. Accordingly, the determined problems were classified under three subheadings based on students' views.

\subsubsection{Characteristics of German Language}

All of the students reported similar views regarding the learning difficulties stemming from the characteristics of German language. Especially, all nouns in German are defined by three grammatical gender such as der (masculine), die (feminine), and das (neuter). The article of plural nouns is die. The grammatical gender is not related to biological gender; however, students constantly try to associate nouns they have learned in German with a gender. Therefore, this causes students to confuse the definite articles of nouns in German. For example, with respect to the grammatical gender, the students said:

I cannot memorize German nouns because of the fact that each noun is defined by gender. I constantly confuse the article of nouns. Consequently, I am discouraged to learn German. [Interview, S15]

There are too many rules in German. I was very surprised when I first heard that each noun was assigned a grammatical gender. I have seen the tips that I can define the articles of the nouns without looking for them in the dictionary or on many websites. However, I have always witnessed that those rules do not apply. [Interview, S18]

I cannot understand why nouns are defined with a gender. For example, the noun "der Tisch" is not an organism. I am astonished, how it has a male gender. So, my mind is constantly getting confused. [Interview, S21]

In addition, the students have difficulty in recognizing change of grammatical gender according to German case system. The current cases are defined as nominative, accusative, dative and genitive. The grammatical genders vary across ordering of nouns in sentence. As a result of these differences, the students had difficulty in clearly understanding the cases in German. Below are students' views on the article system in German:

I cannot make the sentence because of German case system. The articles of nouns change according to this rule. I confuse, when and how the nominative, accusative, dative and genitive cases are used in sentence. [Interview, S23]

German cases are not only related to nouns but also prepositions. There are prepositions introduced by the cases. Some prepositions are used both accusative and dative cases. This confusing situation frustrates me. [Interview, S27]

\subsubsection{Linguistic Habitus}

The concept of linguistic habitus is generally described as learning habits ignored the grammatical system of second foreign language due to their learning habits relating to the language system of English (Bourdieu, 1990). The students have difficulty in learning German because of their learning styles and strategies based on grammatical structure and phonological facts of English. English is taught as a second language almost all over the world. English is the first target language to be learned in early ages. This may lead individuals to acquire English rather than learning it. Consequently, the perception of foreign languages may develop depending on the language system of L2 English. When intended to learn another foreign language, language learners may compare new target language with key facts of L2 English such as grammatical structure, pronunciation, word order, declension and inflection. Within the scope of the current study, it was determined from the interviews that students refused the German language system and associated it with L2 English continuously. Especially, all German nouns are capitalized. The study findings from the interviews indicate that the students always ignore this rule depending on their learning habits in English. In addition, they have difficulty in verb inflections. German verbs are inflected differently than in English and each pronoun gets its own inflectional suffix. The findings show that the students cannot distinguish inflectional verb suffixes of pronouns. Therefore, it can be argued that this aspect of German language intimidates the students and complicates their learning processes. For example, with respect to grammatical differences, the students said:

I cannot distinguish the gender markers in German, because English nouns are not assigned a gender. [Interview, S3]

I have difficulty in verb inflection in German. Because verbs in English do not change according to pronoun as in German. Verbs in English are assigned inflectional suffix -s only in third-person singular. I learn German at the university for the first time. And it is a little difficult to quit this habit. [Interview, S5]

The fact that there are no gender markers of nouns in English develops a feeling as if there are no gender 
markers in German. I cannot perceive the differences of German language. This leads me to discourage learning German. [Interview, S18]

In addition, the phonological differences were defined as another learning difficulty in L3 German experienced by the students. The German alphabet, as in English, includes five main vowels such as $a, e, i, o, u$. However, it has different vowels called umlaute such as $\ddot{a}, \ddot{o}$, and $\ddot{u}$. In addition, most German words include diphthongs which are the combination of two vowels as in English. These diphthongs are $a u, e u, i e, e i$, $\ddot{a}$. The students tended to pronounce German words in a way similar to that in in English. For example, the most common mistake was observed in the pronunciation of "ie" diphthong. The students pronounced the grammatical gender "die" by associating with the English verb "die". However, there are not only diphthongs which are the combination of two vowels but also two paired consonants in German. Especially, the combination of s and t are found commonly at the beginning of German words, just like in English. For example, English word street and German word Strasse have the same meaning, but they are pronounced differently. Consequently, the findings of the current study from the interviews underline that the students mispronounced German words under the influence of English, instead of considering the phonological facts of German language. For example, with respect to pronunciation in German, the student said:

It is not very difficult to pronounce German words. However, most of German words are similar to English. I always pronounce these words according to English. I know that German is phonologically different from English. But I overlook the phonological facts of German unintentionally. [Interview, S11]

I have been studying English for years. I don't think I can learn German when I haven't fully learned English. I think German is a very different language from English. Nevertheless, I always pronounce it, just like English. [Interview, S16]

The last difficulty in learning German experienced due to the effect of L2 English was observed in word order. Building a sentence in L3 German differs from that in L2 English. If a sentence is built in modal verbs, perfect tense, future tense or past perfect tense, the main verb is always found at the end of the sentence. Because main verbs are found after the auxiliary verbs, which leads students to order German words incorrectly. However, L3 German words are ordered differently than in L2 English, when building sentences with conjunctions. The auxiliary verbs and main verbs are found together at the end of the sentence. For example, with respect to difficulties in building a sentence in L3 German based on linguistic habitus, the students said:

English always comes to my mind when writing sentences in German or answering questions when you ask a question in German. When said a foreign language, I only think of English. The fact that most of the English words are similar to German leads me to associate German words directly with English. I think it's a habit. I think it will be a little difficult for me to quit this habit. [Interview, S2]

Ordering German verbs in a sentence is getting complicated. For example, verbs are found at the end of the sentence in some cases. The usage of verbs varies from conjunctions to conjunctions. However, I sometimes notice similar grammatical use in German, when compared it to English. Consequently, I keep making mistakes and am unable to settle a matter. [Interview, S7]

I think German is a very difficult language. Compared to English, there are a lot of grammar rules in German and they are really complex. Especially the definite articles of German nouns are really difficult to understand. If you don't fully understand the cases in German, it is really hard to make a sentence. In addition, all nouns are found in capital letters. Therefore, I realize that I ignored the capitalization of nouns in the exams. I think it seems to take a long time to recognize the linguistic characteristics of German language. [Interview, S17]

\subsubsection{Effect of Native Language}

The findings of current study indicate that the native language of the students positively or negatively affects learning L3 German. By looking at the fact that each language has some unique characteristics, it is not possible to translate any language into another language exactly. When translating a text into our native language, the translation is usually realized considering the closest phrases in our language.

Among the participants, it was observed in the classroom practices that they tried to express themselves by associating them with L1 Turkish, when building L3 German sentences. Afterwards, it was determined that the students misstated the expressions in L3 German due to incorrect lexical choice. Based on the current fact, it was aimed to be investigated whether students had difficulties stemming from the characteristics of L1 while learning L3 German. Accordingly, the students were asked to what extent they have information about the linguistic characteristics of L1 Turkish. The question focused on the grammatical structure, word order and lexical choice of 
L1 Turkish. When the students' views on this question were investigated, it was determined that the students do not properly recognize linguistic characteristics of L1 Turkish. Particularly, the student reported that they could not properly grasp the grammatical rules of L1 Turkish, choose correct words, and notice the possibility of reflections cultural differences in the linguistic development process, when expressing themselves. As a consequence, it can be assumed that individuals who cannot exactly acquire the linguistic characteristics of L1 may experience difficulties in expressing themselves in target language due to the linguistic deficits such as incorrect word order and wrong lexical choice and, in understanding events and facts based on behavior patterns of language that develop depending on daily lifestyle. The students' views about the current question of the study were directly cited as follows.

There are differences in pronunciation between Turkish and German, despite the fact that some words in German are pronounced as written. Because all nouns in Turkish are pronounced as written. Besides, I can say that word order within a Turkish sentence is different from German. [Interview, S20]

When I am asked the items of the sentence in Turkish, I think of only subject and predicate of the sentence. I have no idea what exactly other items are. [Interview, S22]

I lastly was in primary school, when I took Turkish lesson. I do not know enough about this subject. [Interview, S24]

I do not know exactly what the difference between definite noun phrase and adjective clause is. I studied on these course subjects for a moment, while preparing for university exams. But I really don't remember now. [Interview, S26]

While attending German lessons, I realized that I did not know Turkish, which is my native language. Especially, I had no idea about the items of sentence in Turkish. [Interview, S27]

While attending German lessons, I realized that there was a relationship similar to the sentence structure of Turkish. As in Turkish, there are the cases in German. I was not aware of these when speaking Turkish. But now I am learning the characteristics of Turkish while I am learning German. [Interview, S29]

\subsection{Effective Factors}

In the current study, the students were asked about what their perceptions of L3 German in order to determine the difficulties experienced in the learning process. As a result of the data obtained, it was determined that the students had low levels of motivation to learn L3 German. Additionally, they have negative attitudes towards learning German. When students' views were analysed, it was clear that they could not adequately show their self-confidence in learning L3 German and their level of readiness for the learning process in L3 German was not at the desired level. In the context of the current study, the concepts of motivation, attitude, readiness and self-confidence emerged as the learning difficulties in L3 German. The concepts in question were classified by the researcher under the heading of effective factors.

\subsubsection{Motivation}

The current literature underlines that motivation is one of the most important factors that triggers the language learning and teaching process. Individual differences may affect interests of the students in learning a language. In other words, investigating the students' perceptions of L3 German may aid to reveal the challenges experienced by students in the learning process, because motivation may affect the learning process positively or negatively, revealing the students' desire to learn and interest in L3 German is important. Therefore, exposing the reasons of learning difficulties resulting from lack of motivation of students may contribute to developing new teaching methods and techniques, and to designing sustainable course materials that can be used effectively in classroom practice in the future.

When the students' views were examined, it was determined that their motivation for learning L3 German was low. In other words, the motivation factor caused students to have low academic achievement and to experience the difficulties in the learning process of L3 German. The findings indicate that the low motivation of the students may be associated with the reasons discussed under the headings such as linguistic facts and external factors. Especially the financial possibilities of students, the availability of German language in the future and characteristics of German language cause a decrease in their desire to learn L3 German. The current study indicates that lowly motivated students have difficulties in learning L3 German. Accordingly, the students' views were presented as below cited.

German is a difficult language for me, and I am not trying to learn it in my spare time. Clearly, I have no desire to learn German. [Interview, S6] 
At first, I had a desire to learn German. However, the fact that all nouns in German are assigned grammatical gender and I had to recognize them decreased my interest in learning German. [Interview, S8]

In the future, I do not think that German will give me a positive advantage for finding a good job. Therefore, I do not make any efforts to learn German outside school. [Interview, S9]

After I had scored a low grade in the German exam, I was not eager to learn German. [Interview, S10]

The complexity of German case system has decreased my eager to learn German. Because, I can't succeed in making a German sentence. Consequently, I am lowly motivated to learn German. [Interview, S11]

I must work due to monetary problems. I am not interested in other lessons, not only in German. I do not want to study under such circumstances. [Interview, S12]

I am not exactly good at English. Moreover, German is a new language for me. In the context, I don't think learning German is exciting. [Interview, S14]

I think I don't have the ability to learn any foreign languages. So, I have no interest or desire for German. I would not attend to the lesson, if it was not obligatory. I feel sleepy in lesson because my motivation is low. [Interview, S15]

\subsubsection{Attitude}

The concept of attitude can be defined as the behavioral pattern in which individuals show positive or negative behavior towards events and facts based on motivation factor. However, there is debate on the definition of the concept of attitude in the current literature. In accordance with the data obtained, the researcher considered the attitude concept as an effective factor that occurs within individuals as a result of external factors. Based on the results of the content analysis of the students' views, it was assumed that their attitudes towards learning L3 German were shaped as a result of the linguistic feature of German, socio-cultural developments and financial problems. In particular, their negative attitudes towards German language led them to experience the learning difficulties in L3 German. Accordingly, the students' views were as follows:

Turkish and English nouns are capitalized at the beginning of the sentence. However, this usage is different in German. German confuses my head, which is not written big in all names. The capitalization of all nouns in German confuses me. [Interview, S20]

It was always said to be a rough language for German. So, I never thought of learning German. [Interview, S23]

My brother graduated from the Department of German Language Teaching. He hasn't been appointed for 5 years. Therefore, it isn't given the importance for learning German in Turkey and I find it unnecessary. [Interview, S28]

English is a global language learned by almost everyone all over the world. So, there is no point in learning German. [Interview, S29]

\subsubsection{Readiness}

The target group of the current study was comprised of the students who started learning German for the first time. Frankly, it was inevitable that the students had difficulty in learning L3 German, owing to the fact that they encountered a different language after L2 English which has been taught since the early ages. From this point of view, it can be assumed that the concept of readiness is one of the most important effective factors for a successful learning process. Within the scope of the current study, it was determined that students did not have readiness to learn L3 German. Especially, the students stated that they were not able to distinguish the phonological characteristics of German language and the capitalization of all nouns in German. The findings indicated that the students could not understand why all nouns in German are assigned the grammatical gender. Furthermore, the students stated that they mixed the existing gender markers of nouns in German because of associating grammatical genders with biological genders. The students expressed their opinions about the fact that the exchange of the grammatical genders of nouns was very complex on the basis of German case system. They added that they aligned the words based on the sentence structure of L2 English, when building a sentence. Based on the students' views, it can be assumed that the students cannot create awareness of the language characteristics of German language and are not ready to learn L3 German. The related quotations were presented as below:

I have a hard time guessing the gender markers of German nouns. [Interview, S5] 
I cannot understand the changes of the gender markers, when I make a sentence in German. [Interview, S7]

When I look for the gender markers of some German nouns in the dictionary, I cannot understand why the genders of them are female or male. [Interview, S9]

It is really difficult to understand the gender markers of the nouns. For example, das is used for non-living things. I do not understand why das is used for the word "Mädchen". [Interview, S10]

I noticed some similarities between German and English. However, I am still unable to grasp the order of words in some sentence structures. [Interview, S11]

\subsubsection{Self-Confidence}

Self-confidence is another effective issue that has an impact on increasing learning achievement and motivating students to reach their learning goals. Research findings indicated that students experienced the learning difficulties in L3 German due to lack of self-confidence. Based on their fear of making mistakes, the students stated that they had difficulty in making a German sentence. It can be argued that preparing foreign language exams towards testing grammatical knowledge leads students to acquire this habit. Therefore, it can be assumed that the students lose their motivation due to the complexity of the characteristics of German language. Regarding this, the students stated that they refrained from building German sentences. This inevitably leads to the students to lose their self-confidence in learning L3 German. The statements reflecting the students' views regarding this situation are quoted as follows:

I am having difficulty speaking German because of the fear of making mistakes. [Interview, S4]

I am afraid to answer when asked questions in German lessons. [Interview, S5]

I think I cannot learn German because I cannot understand the German case system. [Interview, S6]

I don't believe I can pass the German exams after seeing all the grammatical rules in German. [Interview, S7]

I do not think I can distinguish the change of gender markers of nouns in the cases. [Interview, S8]

The way the German words are ordered within a sentence is quite complicated to me. I think I cannot deal with this. [Interview, S9]

I watched videos regrading learning German on Yotube. However, German is spoken very quickly. So, I don't believe I can learn German and speak it. [Interview, S11]

\subsection{External Factors}

Based on the students' view, it was determined that socio-cultural developments and financial matters affected the learning process in German. These factors were discussed separately under the heading "external factors".

\subsubsection{Socio-Cultural Developments}

The characteristic of the learning environment can shape individuals' worldview and their perspectives on events and facts positively or negatively. It can be assumed that the relations of students with their colleagues, the city in which they study at university and cultural activities affect the development of the foreign language learning process. Cultural differences can be observed in almost every city in Turkey. The students from different cities study in the same classrooms of the universities. This creates the social environment in which intercultural interaction intensely coexists. In addition, the fact that cities are ready for this new cultural interaction and change created by universities affects the students' adaptability to both their department and the city.

Besides, the findings showed that having a university degree does not have distinctive value. To put it more clearly, the students had a perception that the criteria for finding a job in the future is equivalent to a 4-year bachelor's degree. Also, it was determined that the students' desire to work in a job in the future was low regarding the department they received their undergraduate education. As a result of the study findings, it was revealed that there was a perception in the existing society that those who do not study at any university are considered as inadequate individuals. This reality promotes the individuals to complete their undergraduate education at any university and in any department that they do not want and causes them to work in a job unrelated to the department of graduation. As a consequence, this inevitably leads to a decrease in the interest and success level of students in learning L3 German. The students think of L3 German lessons as a course that must be passed only to graduate from their program. The students' views related to this finding were presented below:

In the future, I do not intend to do this job. Just a 4-year diploma is enough for me. Because I think of 
being a cop. That's why learning German does not make any sense to me. [Interview, S4]

I am a commissioned officer in the navy. My goal is to participate in pilotage training in Hungary and become a pilot after getting a 4-year bachelor's degree. I mean, it is not very important for me to get a high grade in German lesson. it is enough for me if I pass the course. [Interview, S5]

This is a very expensive city, food, house rents, etc. for me. So, I have no social activity. Therefore, it becomes unbearable for me to attend classes and study. When I do not attend German classes, the topics accumulate a lot and I find it difficult to understand. As a result, my interest in learning German is decreasing. [Interview, $S 7$ ]

There is no place in the city where I can do social activities with my friends. I also study with different people from different cities. There are a lot of cultural differences between us. Sometimes it may become almost impossible to do something together. [Interview, S8]

We usually meet with friends after school and go to a cafe or sometimes we gather at home and play PlayStation. As such, I spend most of my time playing games instead of studying. For this reason, I cannot spare time to study German. [Interview, S9]

I don't like city and university. Because there is no activity that I can blow off steam in my spare time. Consequently, my desire to go to university decreases. I can't attend classes when I don't go to school. German lesson is unbearable for me because I don't have enough interest in the lessons. [Interview, S12]

I only study college for my family's request. When I get the diploma, I will frame it and hang it on the wall of our house. So, I have no interest not only in German but also in other lessons. It is enough for me if I pass the lesson. [Interview, S18]

I want to engage in trade after the graduation. My father has a shop. Since he was unable to study at the university in time, he forced me to study at the university. I study at this department because my father wanted it. So, if I get valid grade to pass the lessons, it is enough for me. However, I do not think that learning German will be beneficial for me in the future. [Interview, S20]

\subsubsection{Financial Matters}

Individuals' ability to sustain their social and psychological development positively may be directly proportional to their financial possibilities. The current innovations of our age have increased the affordability of educational services. University education leads students not only to cope with their lessons but also to struggle to meet their vital needs such as housing, nutrition and social activities. Almost all of these requirements are money- related. The findings of the current study showed that one of the most important reasons for students' difficulties in learning L3 German was related to the availability of economic conditions. In Turkey, the students get financial support from their families in order to survive in the cities in which they study. Besides, they maintain their life with various scholarships and higher education credits. Correspondingly, they are asked to fully attend their lessons, not to be constantly preoccupied with the monetary problems, and to pay their attention entirely to the lessons.

On the other hand, the students had difficulty in fulfilling their vital requirements depending on their current budgets in order to survive as a result of the price increases in food and accommodation expenses. This led the students to look for part-time jobs out of school time. Accordingly, it was determined that the students could not attend their lessons due to the inability to provide flexibility between the working hours and course hours. The findings indicated that the students who could not attend the lessons had difficulties in following the course content. Furthermore, after a while, they had the perception that earning money was more important than attending lessons. The students not only missed the lessons, but also spent their free time to rest as they were tired because of work. Consequently, the findings indicated that the students did not take the time to learn L3 German. The quotations from the students' views on this issue are as in the following:

I cannot come to most lessons because I have to work at times. [Interview, S11]

Since I work at part-time shopping mall during the day, I cannot attend most lessons. Since I am tired rather than standing, I naturally rest after eating when I go home. Frankly, I don't spend time studying any lessons. [Interview, S11]

Home rental prices in the city are very high. The financial support I get from my family is not enough to meet my rent and personal needs. My working hours and my course hours sometimes overlap. I may be fired, if I don't go to work. After the work I go directly to the house and eat something. So, I don't have time to study German. [Interview, S22] 
The money sent by my family is not enough for me. I applied to many scholarships. However, I did not get any scholarships. I do not want to get a student loan. Because I thought that I couldn't pay it in case there was a problem finding a job in the future. So, I work in a cafe for 30 Turkish liras. I don't really have time to study German. [Interview, S23]

My two brothers apart from me are studying at university, too. My family is trying to equally support all of us financially. But it is not enough. So, I work as a receptionist in a hotel. The working hours are constantly changing. I cannot study German as I have difficulty in following my lessons. [Interview, S26]

I have to take care of my brothers as the eldest of the family, because we lost my father. I have to study and earn money. However, I miss my classes, since my priority is to make money. So, I don't have the time to study German since I work at the cafe late at night after school. [Interview, S27]

\section{Discussion}

Determining the learning difficulties of undergraduate students in L3 German is of significance in order to develop new teaching methods and design course materials. The findings of the current study reveal three main difficulties in learning L3 German. These are (1) linguistic facts, (2) effective factors and (3) external factors.

The linguistic facts in this study are related to the characteristics of the German language and the effect of L1. Turkish undergraduate students have difficulty in learning German because of the phonology, orthographical structure, sentence structure, meaning of words and grammatical gender of the German language. Vellutino and Scanlon (1986) argued that language learners, who have problems with writing and reading, incorrectly code phonological, orthographical and syntactical structure of the foreign language on the basis of their L1 (see Ganschow \& Sparks, 2001). Similarly, Danansooriya (2010) found that the undergraduate students in Sri Lanka experienced phonological difficulties in L3 German depending on their L1. On the contrary, Mechsheryakova (2018, p. 67) in her study comparing German and Mandarin Chinese argued that foreign language learners did not have difficulty in learning German with effective methods and techniques despite the different language structures. However, the findings of the current study indicate that Turkish undergraduate students pronounce the German words incorrectly due to the effect of L2 English. Consequently, it was revealed that L1 leads to Turkish undergraduate students to have challenges with semantic aspects of L3 German.

Apart from the linguistic facts, it was determined that effective factors such as motivation, attitude, readiness and self-confidence affect the learning difficulties in L3 German experienced by undergraduate students. The findings of the current study show that students with low motivation have difficulties in learning L3 German and their interest in learning L3 German is low. Lightbown and Spada (2006, p.12) argued that highly motivated students have a high achievement in learning a language in the classroom practices. On the other hand, Oroujlou and Vahedi (2011, p. 997) indicate that the motivation is one of the most important factors that affects the foreign language learning process inside and outside the classroom. However, Ganshow et al. (1998, p. 2) discussed whether the difficulties in learning a language result from motivations and attitudes of language learners, or not. On the contrary, Sparks and Ganschow (1996) determined that the factors such as motivation, attitude and anxiety positively affect improving the language skills of language learners. As a consequence, the mentioned factors may be described as internal factors that affect the learning difficulties in foreign language learning. The concept of motivation was described as the generic term in the current study. The learning difficulties were broadened under the concept of motivation. In the context, the motivation deals with readiness, attitude and self-confidence of students towards learning L3 German in the study.

The last finding concerning learning difficulties in L3 German was related to the external factors. The external factors were divided into two subfactors such as socio-cultural developments and financial matters. In this study, it was determined that the Turkish undergraduate students had difficulties in learning L3 German due to the socio-cultural characteristics of the city where their university is located, the views of the society about individuals who have a bachelor's degree, and the current social environment at the campus. Duffy and Cunningham (1996, p. 182) claimed that having a socially rich environment and co-operating with experienced peers accelerate the learning process. Nacar-Logie (2004, pp. 178-179) pointed out that the awareness of the complexity of the major phenomena in which cultural differences are clearly observed, the ability to recognize cultural meanings in the target culture, and the ability to use it in the social and professional field play an important role in overcoming difficulties in the language learning process (see Yusufoğlu, 2017, p. 48). However, these are related to socio-cultural differences between the target language and L1. In the current study, it has been determined that there are cultural differences even in different geographical regions of the same society, and the cultural differences that students have may lead to certain learning difficulties. The external social environment in which individuals grow up is of great importance in determining the difficulties experienced in foreign language learning 
(Jaramillo, 1996). Accordingly, the findings of the current study indicated that financial problems cause Turkish undergraduate students to have difficulty in learning L3 German.

\section{Conclusion}

In the current study, the learning difficulties in L3 German experienced by Turkish undergraduate students who study at three different academic programs of Iskenderun Technical University, were determined. As a result of the study, these difficulties were discussed and interpreted under three main categories that are linguistic facts, effective factors and external factors.

The characteristics of the German language, its linguistic habitus and the effect of L1 were described as the learning difficulties in L3 German emerging in the context of linguistic facts. In particular, the fact that students came across a language with different language characteristics unlike their conventional foreign language perception complicated the learning process of L3 German. It was an unusual situation for the students that all nouns in German are capitalized and are assigned grammatical genders. Moreover, the students were confused due to the German case system which is determinant in the sentence construction. Almost all of the students agreed on grammatical gender of nouns and German case system, when asked which language learning difficulties they experienced in L3 German. On the other hand, the language system of L2 English taught from an early age led the students to have difficulties in learning L3 German. As a result of the study, it was determined that the students ignored the linguistic characteristics of L3 German due to the commitment on the language system of L2 English, when building German sentences. Accordingly, the existence of similar word structures in German and English led the students to pronounce the German words incorrectly and they could not distinguish linguistic differences. Based on the results of the current study, it can be assumed that ignoring the linguistic differences leads to concrete errors in learning L3 German. In contrast, the effect of L1 manifests itself in an abstract dimension. In other words, the students try to express themselves in L3 German, by transferring the events and facts reflecting the cultural and linguistic characteristics of their L1 to L3 German in the semantic dimension. This makes it difficult for students to be understood.

In the current study, the students were asked about their views about teaching L3 German, and whether they made any effort to learn L3 German outside school. The findings indicated that the students' views were closely related to their cognition in the learning process. Accordingly, it was determined that the concepts of motivation, attitude, readiness and self-confidence emerged in the context of effective factors. The students stated that their struggle for survival as a result of their current financial situation and their perception towards the linguistic characteristic of German decreased their desire to learn L3 German. This led the students to lose motivation. The lack of motivation prevented the students from psychologically acting to learn L3 German. In other words, the lack of motivation led them to experience learning difficulties in L3 German. Moreover, it was determined that the students had negative attitudes towards L3 German and its learning process due to the lack of motivation. The reason behind their negative attitudes can be explained with the level of readiness for learning L3 German. Especially, the findings of the study underlined that the students had difficulty in learning L3 German due to the influence of L2 English taught since the early ages and its learning strategies. Moreover, the students lost their self-confidence to learn L3 German as a result of the lack of motivation, their negative attitudes towards L3 German and the low level of readiness for learning process. Consequently, the above-mentioned concepts discussed in the context of effective factors do not develop independently. These can be assumed as effective factors that develop interrelatedly depending on external factors.

Finally, it was determined within the scope of the current study that students had difficulties in learning L3 German depending on external factors. As a result of the data obtained from student views, it can be understood that the learning process develops negatively depending on socio-cultural developments and financial matters. For this purpose, the cultural structure of the city in which the students study, their social circle and the society's overall perspective of university education were discussed in the context of socio-cultural developments. In particular, most of the students stated that they preferred to study in university because their families wanted them to do so. And they added that they wanted to work in jobs not related to their majors in university in the future. The existing perception of the students emerging as a result of society's approach inevitably decrease their interest in learning L3 German. Besides, it was determined that the students struggled to earn money in order to continue their university education and survive.

Because of the low financial support which they receive from their families, most of the students tend to work in a job after school instead of studying for their classes. However, it was determined that the students gradually started missing the classes after a while and the desire to make money became more attractive than attending classes.

Consequently, it can be said that the difficulties determined within the scope of this study are related to each other. 
These difficulties with regard to the target language, students' cognition and external factors develop simultaneously and lead students to have difficulties in the process of learning L3 German.

\section{References}

Bardel, C., \& Falk, Y. (2007). The role of the second language in third language acquisition: The case of Germanic syntax. Second Language Research, 23(4), 459-484. https://doi.org/10.1177/0267658307080557

Berkes, É, \& Flynn, S. (2012). Further evidence in support of the cumulative-enhancement model: CP structure development. In J. Cabrelli, S. Flynn, \& J. Rothman (Eds.), Third language acquisition in adulthood (pp. 143-164). Amsterdam: John Benjamins Publishing. https://doi.org/10.1075/sibil.46.11ber

Bourdieu, P. (1990). The logic of practice. Stanford University Press.

Braun, V., \& Clarke, V. (2006). Using thematic analysis in psychology. Qualitative Research in Psychology, 3(2), 77-101. https://doi.org/10.1191/1478088706qp063oa

Cenoz, J. (2001). The effect of linguistic distance, 12 status and age on cross-linguistic influence in third language acquisition. In J. Cenoz, B. Hufeisen, \& U. Jessner (Eds.), Crosslinguistic influence in third language acquisition: Psycholinguistic perspectives (pp. 8-20). Clevedon: Multilingual Matters. https://doi.org/10.21832/9781853595509

Danansooriya, M. (2010). Learning difficulties encountered in learning German as a foreign language at the universities in sri lanka. Paper presented at the Research Symposium 2010-Faculty of Graduate Studies, University of Kelaniya. Retrieved from http://repository.kln.ac.lk/handle/123456789/4657

De Angelis, G. (2005). Interlanguage Transfer of Function Words. Language Learning, 55(3), 379-414. https://doi.org/10.1111/j.0023-8333.2005.00310.x

Duffy, T. M., \& Cunningham, D. J. (1996). Constructivism: Implications for the design and delivery of instruction. In D. H. Jonassen (Ed.), Handbook of research for educational communications and technology (pp. 170-198). New York: Simon and Schuster MacMillan.

Ehrman, M., \& R. Oxford. (1990). Adult language learning styles and strategies in an intensive training setting. The Modern Language Journal, 74, 311-327. https://doi.org/10.1111/j.1540-4781.1990.tb01069.x

Epimakhova, A., Pechinkina, O., \& Tarasova, N. (2019). Difficulties in teaching Russian as a foreign language for beginners in the context of European multilingualism. Advances in Social Science, Education and Humanities Research, 360, 77-81. https://doi.org/10.2991/emssese-19.2019.27

Falk, Y., \& Bardel, C. (2010). Object pronouns in German L3 syntax: Evidence for the 12 status factor. Second Language Research, 27(1), 59-82. https://doi.org/10.1177/0267658310386647

Flynn, S., Vinnitskaya, I., \& Foley, C. (2004). The cumulative-enhancement model for language acquisition: comparing adults' and children's patterns of development in first, second and third language acquisition of relative clauses. International Journal of Multilingualism, 1(1), 3-16. https://doi.org/10.1080/14790710408668175

Ganschow, L., \& Sparks, R. (2001). Learning difficulties and foreign language learning: A review of research and instruction. Language Teaching, 34(2), 79. https://doi.org/10.1017/S0261444800015895

Ganschow, L., Sparks, R. L., \& Javorsky, J. (1998). Foreign language learning difficulties. Journal of Learning Disabilities, 31(3), 248-258. https://doi.org/10.1177/002221949803100304

Gardner, R., \& Lambert, W. (1959). Motivational variables in second language acquisition. Canadian Journal of Psychology, 13, 266-272. https://doi.org/10.1037/h0083787

Groseva, M. (1998). Serves the L2 system as one foreign language learning model? In B. Hufeisen, \& B. Lindemann (Eds.), Tertiary languages, theories, models, methods (pp. 21-30). Tübingen: Stauffenburg Publishing.

Hufeisen, B. (2003). Brief introduction to the linguistic basis. In B. Hufeisen, \& G. Neuner (Eds.), Multilingualism concept - tertiary language learning - German to English (pp. 7-11). Strasbourg: Council of Europe Publishing.

Ishag, A., Altmayer, C., \& Witruk, E. (2015). A comparative self-assessment of difficulty in learning English and German among Sudanese students. Journal of Language and Cultural Education, 3(2), 32-38. https://doi.org/10.1515/jolace-2015-0012

Iwasaki, K. (2001). Internet's role in German language education in Japan. Retrieved from 
https://www.scribd.com/document/368908965/Internets-Role-in-German-Language-Education-in-Japan

Jaensch, C. (2011). L3 Acquisition of German adjectival inflection: A generative account. Second Language Research, 27(1), 83-105. https://doi.org/10.1177/0267658310386646

Jaramillo, J. A. (1996). Vygotsky's sociocultural theory and contributions to the development of constructivist curriculum. Education, 117, 133-140.

Jessner, U. (2003). On the nature of crosslinguistic interaction in multilinguals. In B. Cenoz, B. Hufeisen, \& U. Jessner (Eds.), The Multilingual lexicon (pp. 45-55). Dordrecht: Kluwer Publishing.

Jessner, U. (2006). Linguistic awareness in multilinguals: English as a third language. Edinburgh: EUP Publishing. https://doi.org/10.3366/edinburgh/9780748619139.001.0001

Jeuk, S. (2010). German as a second language at school. Basics - diagnosis - promotion. Stuttgart: W. Kohlhammer Publishing.

Kolabinova, T. I., Zaripova, A. N., Zaglyadkina, T. Y., \& Yusupova, L. G. (2015). English as an additional language for Russian university students learning German as the first foreign language. Procedia - Social and Behavioral Sciences, 199, 334-339. https://doi.org/10.1016/j.sbspro.2015.07.556

Kupisch, T., Snape, N., \& Stangen, I. (2013). Foreign language acquisition in heritage speakers. Linguistic Superdiversity in Urban Areas: Research approaches, 2, 99. https://doi.org/10.1075/hsld.2.08kup

Lay, T. (2017). Learning difficulties of Chinese learners of German in the beginners' course taking into account Chinese as the first language and English as the first foreign language. Zielsprache Deutsch, 44(2), 19-38.

Leung, Y. K. I. (2005). L2 vs. L3 initial state: A comparative study of the acquisition of French DPs by Vietnamese monolinguals and Cantonese-English bilinguals. Bilingualism: Language and Cognition, 8(1), 39-61. https://doi.org/10.1017/S1366728904002044

Leung, Y. K. I. (2006). Full transfer vs. partial transfer in L2 and L3 acquisition. In inquiries in linguistic development. In R. Slabakova, S. Montrul, \& P. Prévost (Eds.), Honor of Lydia White (pp. 157-88). Amsterdam: John Benjamins Publishing. https://doi.org/10.1075/z.133.10leu

Lightbown, P., \& Spada, N. (2006). How languages are learned (3rd ed.). Oxford: Oxford University Press.

Little, D. (2017). Responding to the challenge of student diversity: Learner autonomy and constructive alignment. In C. Harsch, H. P. Krings, \& B. Kühn (Eds.), Content and diversity - new challenges for language learning and teaching at universities. Income from the 5th Bremen symposium, foreign languages in teaching and research (pp. 13-30). Bochum: AKS Publishing House.

Mechsheryakova, A. (2018). Difficulties in Learning Western and Oriental Languages: A Comparative Approach to Learning German and Mandarin Chinese. Retrieved from https://recipp.ipp.pt/bitstream/10400.22/12648/1/alexandra_mechsheryakova_MISB_2018.pdf

Nacar-Logie, N. (2004). The importance of creating cultural skills in foreign language teaching and the scientific aspect. Hasan Ali Yücel Faculty of Education Journal, 1, 173-180.

O’Malley, J. M., \& Valdez-Pierce, L. (1996). Authentic assessment for English language learners: Practical approaches for teachers. New York: Addison-Wesley Publishing Company.

Oroujlou, N., \& Vahedi, M. (2011). Motivation, attitude, and language learning. Procedia: Social and Behavioral Sciences, 29, 994-100. https://doi.org/10.1016/j.sbspro.2011.11.333

Robinson, P. (2002). Effects of individual differences in intelligence, aptitude and working memory on adult incidental SLA. In P. Robinson (Ed.), Individual differences and instructed language learning. Language learning and language teaching series (pp. 211-256). Philadelphia: John Benjamins Publishing. https://doi.org/10.1075/11lt.2.13rob

Rothman, J. (2010). On the typological economy of syntactic transfer: Word order and relative clause attachment preference in L3 Brazilian Portuguese. International Review of Applied Linguistics, 48(2-3), 245-273. https://doi.org/10.1515/iral.2010.011

Rothman, J. (2013). Cognitive economy, non-redundancy and typological primacy in L3 acquisition: Evidence from initial stages of L3 Romance. In S. Baauw, F. Dirjkoningen, \& M. Pinto (Eds.), Romance languages and linguistic theory 2011 (pp. 217-248). Amsterdam: John Benjamins Publishing. https://doi.org/10.1075/rllt.5.11rot

Şekerci-Arıbaş, D., \& Cele, F. (2019). Acquisition of articles in L2 and L3 English: The influence of L2 
proficiency on positive transfer from L2 to L3. Journal of Multilingual and Multicultural Development, 1-18. https://doi.org/10.1080/01434632.2019.1667364

Sparks, R., \& Ganschow, L. (1996). Teachers perceptions of students' foreign language academic skills and affective characteristics. Journal of Educational Research, 89, 172-185. https://doi.org/10.1080/00220671.1996.9941323

Tremblay, M. C. (2006). Cross-linguistic influence in third language acquisition: The role of L2 proficiency and L2 exposure. Ottawa Papers in Linguistics, 34, 109-119.

Vellutino, F., \& Scanlon, D. (1986). Linguistic coding and metalinguistic awareness: Their relationship to verbal and code acquisition in poor and normal readers. In D. Yaden, \& S. Templeton (Eds.), Metalinguistic awareness and beginning literacy (pp. 115-141). Portsmouth, NH: Heinemann Publishing.

Yusufoğlu, S. (2017). The effect of vocabulary teaching on cultural transfer in teaching as a foreign language by moving from the meaning and indication parallelism (Unpublished master's thesis). Hacettepe University, Ankara, Turkey.

\section{Appendix A}

\section{The Interview Questions}

1) What are the difficulties you have experienced in general in the learning process of L3 German?

2) How can you explain the differences between German and your native language? Do you believe that linguistic differences have a positive or negative effect on the way you learn German? and what are these?

3) How can you explain the differences between L2 English and L3 German? Do you believe that linguistic differences have a positive or negative effect on the way you learn German? and what are these?

4) Do you invest your time in learning German outside of school?

5) For what reasons do you relate the low scores you got in the German exams?

6) To what extent are you willing to learn German? If you are reluctant, how can you explain the reasons for this?

7) How would you explain the importance of learning German as a foreign language among your future plans?

Note: The above interview questions were prepared in Turkish and they were asked to the students in Turkish, too. 


\section{Appendix B}

\section{The mid-term and final exams scores of the students who participated in the study}

Table A1. The distribution of students by the cumulative grade point average

\begin{tabular}{|c|c|c|c|c|c|}
\hline Students & Gender & Academic Program & Mid-term exam & Final exam & Average \\
\hline S1 & Male & Travel Management and Tourist Guiding & 73 & 26 & 44.8 \\
\hline S2 & Female & Tourism and Hotel Management & 39 & 48 & 44.4 \\
\hline S3 & Female & Tourism and Hotel Management & 55 & 37 & 44.2 \\
\hline S4 & Male & Aviation Management & 59 & 34 & 44 \\
\hline S5 & Male & Travel Management and Tourist Guiding & 80 & 17 & 43 \\
\hline S6 & Female & Travel Management and Tourist Guiding & 68 & 25 & 42.2 \\
\hline S7 & Male & Travel Management and Tourist Guiding & 61 & 29 & 41.8 \\
\hline S8 & Female & Aviation Management & 53 & 34 & 41.6 \\
\hline S9 & Male & Aviation Management & 17 & 58 & 41.6 \\
\hline S10 & Male & Tourism and Hotel Management & 55 & 31 & 40,6 \\
\hline S11 & Male & Tourism and Hotel Management & 47 & 36 & 40.4 \\
\hline S12 & Female & Aviation Management & 45 & 34 & 40.2 \\
\hline S13 & Male & Travel Management and Tourist Guiding & 65 & 21 & 39.2 \\
\hline S14 & Female & Aviation Management & 50 & 18 & 37.2 \\
\hline S15 & Female & Aviation Management & 27 & 41 & 35.4 \\
\hline S16 & Female & Aviation Management & 52 & 23 & 34.6 \\
\hline S17 & Male & Aviation Management & 25 & 40 & 34 \\
\hline S18 & Female & Tourism and Hotel Management & 57 & 15 & 31.8 \\
\hline S19 & Female & Tourism and Hotel Management & 30 & 35 & 33 \\
\hline S20 & Female & Tourism and Hotel Management & 38 & 28 & 32 \\
\hline S21 & Female & Aviation Management & 45 & 23 & 31.8 \\
\hline S22 & Male & Travel Management and Tourist Guiding & 40 & 25 & 31 \\
\hline S23 & Male & Travel Management and Tourist Guiding & 54 & 15 & 30.6 \\
\hline S24 & Female & Travel Management and Tourist Guiding & 33 & 28 & 30 \\
\hline S25 & Female & Travel Management and Tourist Guiding & 48 & 17 & 29.4 \\
\hline S26 & Male & Travel Management and Tourist Guiding & 15 & 38 & 28.8 \\
\hline S27 & Male & Aviation Management & 35 & 23 & 27.8 \\
\hline S28 & Male & Tourism and Hotel Management & 35 & 20 & 26 \\
\hline S29 & Female & Tourism and Hotel Management & 20 & 20 & 16 \\
\hline
\end{tabular}

\section{Copyrights}

Copyright for this article is retained by the author(s), with first publication rights granted to the journal.

This is an open-access article distributed under the terms and conditions of the Creative Commons Attribution license (http://creativecommons.org/licenses/by/4.0/). 